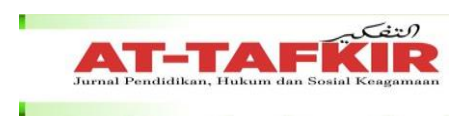

VOLUME 14 NOMOR I TAHUN 2021

P-ISSN : 1979-9357

E-ISSN : $2620-5858$

\title{
Madrasah: Sejarah dan Dinamikanya
}

\author{
Zainuddin \\ Institut Agama Islam Negeri Langsa \\ zainuddin@iainlangsa.ac.id
}

\begin{abstract}
The long journey of madrasas cannot be separated from the long history of this world. Its existence which is full of twists and turns to maintain the existence of Islam becomes something unique to him. Since Indonesia's independence even long before that, the madrasa has contributed a lot in educating the lives of Muslim communities. Although in its journey, it always gets a stumbling around the regulations. The dynamics they experience make madrasa always up to date to discuss.
\end{abstract}

Keywords: Dynamic, History, and Madrasa

Abstrak: Perjalanan panjang madrasah tidak bisa dipisahkan dari sejarah panjang dunia ini. Keberadaanya yang penuh liku-liku dalam rangka mempertahankan existensi keislamanannya menjadi sesuatu yang khas baginya. Sejak Indonesia merdeka bahkan jauh sebelum itu madrasah telah banyak memberi kontribusi dalam mencerdaskan kehidupan masyarakat muslim. Walaupun dalam perjalanannya selalu saja mendapat sandungan regulasi yang mengitarinya. Dinamika yang dialaminya menjadikan madrasah selalu update untuk dibahas.

Kata kunci: Madrasah, Sejarah dan Dinamika

\section{Pendahuluan}

Tradisi pendidikan Islam sudah mengenal jenis institusi pendidikan seperti kuttâb, masjid dan masjid khan. Dalam perkembangannya berikutnya baru muncul madrasah sebagai institusi pendidikan par-excellence (Tibawi 1979, 26). Namun, keduanya merupakan lembaga pendidikan dasar dalam Islam. Adapun yang dimaksud dengan "kuttab" atau "maktab" adalah tempat untuk belajar membaca dan menulis yang ada di rumah guru, sedangkan para siswa datang berkumpul untuk belajar.

Makdisi mengungkapkan bahwa asal muasal pertumbuhan madrasah merupakan hasil tiga tahap; yaitu (1) tahap masjid, (2) masjid khan, dan (3) madrasah (Makdisi 1981, 27). Tahap masjid berlangsung pada abad ke-8 dan ke-9. Masjid yang dimaksud sebagai tempat pendidikan adalah masjid biasa, yang di samping untuk tempat jemaah shalat juga untuk majlis ta'lim (pendidikan). Tahap kedua, adalah masjid khan, yaitu masjid yang dilengkapi dengan bangunan khan (asrama, pemondokan) yang masih bergandengan dengan masjid. Tahap ini mencapai perkembangan sangat pesat pada abad ke-10. Setelah dua tahap perkembangan di atas barulah muncul madrasah yang khusus diperuntukkan sebagai lembaga pendidikan (Maksum 1999, 57-58).

Namun dalam hal tersebut, Syalabi memandang lain, perkembangan dari masjid ke madrasah terjadi secara langsung dengan tidak memakai lembaga perantara. Perkembangan madrasah dapat dikatakan sebagai konsekuensi logis dari semakin ramainya kegiatan pengajian di masjid yang fungsi utamanya sebagai tempat ibadah. Selanjutnya ia mengemukakan alasan/motif berdirinya madrasah di luar masjid.

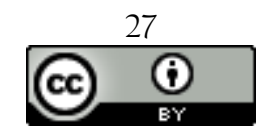

This work is licensed under a Creative Commons Attribution 4.0 International License 
VOLUME 14 NOMOR I TAHUN 2021

P-ISSN : 1979-9357

E-ISSN : 2620-5858

Setidaknya ada tiga yang melatarbelakanginya, yaitu: (1) Halaqah-halaqah yang diselenggarakan di masjid sering mengganggu terutama terhadap orang yang sedang beribadah; (2) Berkembangnya kebutuhan ilmiah sebagi akibat dari perkembangan ilmu pengetahuan; (3) Timbulnya orientasi baru dalam penyelenggaraan pendidikan, seperti di antaranya orientasi berpikir sebagian guru untuk mendapatkan rezeki melalui kegiatan pendidikan (Salaby 1990, 114). Mahmud Yunus menambahkan bahwa motivasi pendirian banyak madrasah di masa pengaruh Turki (Saljuk) adalah untuk mengambil hati rakyat, mengharap pahala dan ampunan dari Allah Swt, memelihara kehidupan anak-anaknya di kemudian hari, memperkuat aliran keagamaan bagi sultan atau pembesar (Yunus 1992, 69-72).

Madrasah sebagai lembaga pendidikan Islam dalam bentuk pendidikan formal sudah dikenal sejak tahun 1066/1067 M (459 H) di Baghdad yang didirikan oleh Nizam al-Mulk, seorang Perdana Menteri Dinasti Saljuk (Nakosteen 1964, 5l). Pendirian madrasah ini telah memperkaya khazanah lembaga pendidikan di lingkungan masyarakat Islam, karena pada masa sebelumnya masyarakat Islam hanya mengenal pendidikan tradisional di masjid-masjid dan dar al-kuttab. Madrasah-madrasah yang didirikan di seluruh kekhalifahan dibiayai secara melimpah. Ia melengkapi madrasahmadrasah tersebut dengan perpustakaan, profesor-profesor terbaik yang dapat diperoleh, dan sistem beasiswa untuk membantu semua mahasiswa (Salaby 1973, 108; Stanton 1994, 50).

Walaupun pendiriannnya (Madrasah Nizamiyah) didorong oleh adanya pertentangan ideologi antara kaum mu'tazilah yang dibantu oleh menteri Amid al Mulk al-Kunduriy dan kaum asy'ariyah yang dibantu oleh Nizham al-Mulk. Di tengah-tengah kemelut sosial politik dan keagamaan yang melanda seluruh propinsi Khurasan, Baghdad dan Iraq, tampillah seorang politikus, negarawan dan ulama muda yang juga dikenal seorang tokoh As'ariyah yaitu Nizham al-Mulk, yang tidak lain adalah menteri Gubernur Alp Arslan. Nizham al-Mulk yang mempunyai banyak pengalaman dilapangan melihat bahwa ideologi negara pada waktu itu berada dalam keadaan terancam bahaya serius dan mimbar-mimbar masjid sudah dijadikan sebagai tempat untuk mengecam kaum As'ariyah oleh pejabat tinggi kesultanan Saljuq pada masa itu. Dalam pada itu, Nizham al-Mulk yang sudah pernah melihat madrasah terdahulu di Khurasan yang memusatkan kajiannya pada studi kemazhaban memberikan inspirasi baginya untuk membela mazhab resmi negara dengan mensosialisasikannya pada seluruh masyarakat dan memimpin mereka keluar dari kemelut menuju perbaikan sosial moral dan taraf hidup. Sejak saat itulah ia konsentrasi pada bidang pendidikan. Untuk itu ia mengadopsi ide madrasah dan memperbarui sistem pendidikannya sedemikian rupa untuk memberanguskan politik Mu'tazilah dan sekutunya, Syi'ah, yang ingin merenggut kewenangan negara dan supremasi Sunni, dan sekaligus meletakkannya sebagai lembaga pendidikan bagi Negara. Lembaga tersebut yang kemudian lebih dikenal dengan nama Madrasah Nizamiyah Naysabur, sebagai madrasah perintis. Nama ini berasal dari nama menteri tersebut yakni Nizham al-Mulk, gelarnya yang diperoleh dari negara dalam kapasitasnya sebagai menteri Saljuq (Mukti 2007, 11l). Namun keberadaan dalam perkembangan lembaga pendidikan dan ilmu pengetahuan telah memberikan kontribusi yang sangat besar. 
VOLUME 14 NOMOR I TAHUN 2021

P-ISSN : 1979-9357

E-ISSN : 2620-5858

Lebih lanjut Hasan Asari menegaskan bahwa Nizamiyah adalah salah satu fenomena penting tidak saja dalam sejarah pendidikan Islam tetapi juga dalam konteks sejarah peradaban Islam secara umum. Hal ini antara lain, adalah karena 1). Pembangunan jaringan Madrasah Nizamiyah adalah merupakan bagian signifikan dari kejayaan peradaban Islam, khususnya di teritorial Dinasti Saljuq (429-590/10381194). 2). Fenomena pembangunan rangkaian Madrasah Nizamiyah terjadi menyusul peralihan kekuasaan dari Dinasti Syi'ah Buwayhi (320-454/932-1062) kepada Dinasti Sunni Saljuq. 3). Sejarah pendidikan Islam menunjukkan bahwa madrasah adalah lembaga pendidikan Islam par excelence sampai periode modern dengan diperkenalkannya lembaga-lembaga modern, seperti universitas (Asari 1994, 79). Pentingnya posisi Madrasah Nizamiyah ini mengharuskan kita untuk melihat motifmotif yang melatar belakangi pembangunannya tersebut dalam konteks realitas historis yang lebih luas dari sekedar konteks pendidikan.

Kajian tentang munculnya madrasah di dunia Islam, banyak ahli sejarah berbeda pendapat. Syalabi menyatakan bahwa madrasah yang mula-mula muncul di dunia Islam adalah madrasah Nizamiyah yang didirikan oleh Nizam al-Mulk, perdana menteri Dinasti Saljuk, pada tahun 1066-1067 M. Pendapat seperti ini juga dikemukakan oleh Philip K. Hitti (Salaby 1970, 410). Sedangkan Muhammad Ațiah alAbrasyi, mengutip dari al-Maqrizi, mengemukakan bahwa Madrasah al-Baihaqiyah adalah madrasah yang pertama didirikan pada akhir abad ke-4 H (abad ke-1l M) (AlAbrasyi 1993, 79). Hampir serupa dengan Athiyah, Richard W. Bulliet berpendapat bahwa dua abad sebelum Madrasah Nizamiyah muncul, di Naisapur sudah berdiri madrasah, yaitu Miyan Dahiyah (Bullier 1972, 48).

\section{METODE PENELITIAN}

Penelitian ini adalah penelitian kepustakaan (library research) (Hadi, 1980). Dengan mengkaji beberapa buku, artikel, sumber lain yang relevan dengan tujuan penelitian.

\section{HASIL DAN PEMBAHASAN}

\section{A. Madrasah di Indonesia}

a. Madrasah Pra-Kemerdekaan

Untuk melihat awal dan cikal bakal munculnya madrarasah di Indonesia tentu tidak terlepas dari sejarah perkembangan Islam itu sendiri. Oleh karena Islam di Indonesia berawal dari Aceh, maka sejarah perkembangan madrasah berawal dari perkembangan Islam di Aceh, yaitu semenjak masa kesulthanan di Aceh sekitar tahun 1520-1675 (Ahmad 1972, 68-71; Lombard 2006, 45; Rahim 2004, 23). Hal ini menunjukkan bahwa pemerintah (sultan) ketika itu sangat memperhatikan perkembangan pendidikan dan ilmu pengetahuan), sehingga banyak lembaga pendidikan yang bermunculan ketika itu. A. Hasjmy (Hasjmy 1978, 68-71) dan Ibrahim (Ibrahim 1993, 269) mengelompokkan pendidikan Islam di Aceh menjadi 5 tingkatan, yaitu meunasah, rangkang, dayah, dayah Teungku Chik, dan Jami'ah. Ibrahim Husein membaginya menjadi dua kelompok, yaitu meunasah untuk tingkat rendah dan dayah untuk tingkat 
menengah dan tinggi. Menurutnya lembaga rangkang termasuk ke dalam pendidikan dayah (Husein 1995, 47-60). Meunasah ketika itu, berfungsi sebagai center of culture (pusat kebudayaan) dan center of education (pusat pendidikan) bagi masyarakat (Hurgronje 1996). Dikatakan center of culture, karena meunasah memang memainkan peranan yang sangat penting dalam kehidupan masyarakat Aceh dan disebutkan center of education, karena secara formal anakanak masyarakat Aceh memulai pendidikannya di lembaga ini. Dengan pengertian ini terkandung makna bahwa sejak dahulu desa-desa di seluruh Aceh telah ada lembaga sekolah yaitu meunasah (Nata 2001, 42). Berdasarkan hal tersebut, banyak pemerhati lembaga pendidikan Islam berkesimpulan bahwa istilah "meunasah" bagi masyarakat Aceh adalah terjemahan dari madrasah (Ibrahim 1993; Idris n.d., 61; Ismail 2002, 5).

Dalam perkembangan selanjutnya, madrasah sebagai lembaga pendidikan Islam klasikal terus berkembang diberbagai wilayah lain di Indonesia (Azra 2017, xviii) yang dikenal dengan berbagai istilah, di Minangkabau dikenal istilah surau dan ribat, sedangkan di Jawa dikenal dengan istilah pesantren (Hasbullah 1995, 27). Memasuki tahun 1900 penyelenggaraan madrasah mengalami pembaharuan. Ada dua faktor utama yang melatarbelakangi terjadi pembaharuan, yaitu: Pertama, ide-ide yang dibawa oleh para tokoh dan ulama yang pulang dari Timur Tengah; Kedua, menyaingi pendidikan yang diselenggarakan pemerintah Belanda (Daulay 2007, 41-42).

Pada Tahun 1907 Syaikh Abdullah Ahmad mendirikan Madrasah Adabiyah di Padang (Daulay 2007, 97). Kemudian Al-Irsyad mendirikan Madrasah Awaliyah, Ibtidaiyah, Tajhiziyah, Muallimin dan Tahsis pada tahun 1913 (Abdul Rachman Shaleh 2004, 19-20). Pada tahun 1915 madrasah ini menjadi HIS Adabiyah yang tetap mengajarkan agama (Daulay 2007, 97). Matlatul Anwar di Menes Banten berdiri pada 9 Agustus 1916 M, mendirikan Madrasah Ibtidaiyah, Tsanawiyah, Aliyah dan Diniyah. Nahdhatul Ulama pada tahun 1926 mendirikan Madrasah Awaliyah, Ibtidaiyah, Tsanawiyah, Muallimin wustha dan Ulya. Persatuan Tarbiyah Islamiyah (Perti) pada tahun 1928 mendirikan madrasah dengan berbagai nama diantaranya tarbiyah Islamiyah, Madrasah Awaliyah, Tsanawiyah, Kuliah Syariah. Tengku Daud Beureuh pada tahun 1930 mendirikan madrasah yang bernama Sa'adah Adabiyah dan Tengku Abdul Rahman Meunasah Mencap mendirikan Madrasah Sarul Huda (Abdul Rachman Shaleh 2004, 19-20). Pesantren Tebuireng, pada tahun 1916 mendirikan sebuah "Madrasah Salafiyah" yang tidak hanya mengadopsi sistem pendidikan modern, tetapi juga memasukkan beberapa pelajaran umum, seperti berhitung, bahasa Melayu, ilmu bumi, dan menulis dengan huruf latin ke dalam kurikulumnya (Azra 1999, xvi; Steenbrink 1991, 36).

Meskipun madrasah dalam modernisasi terus berkembang, pemerintah Belanda tidak berpihak terhadap penyelenggaraan madrasah. Berbagai kebijakan yang muncul selalu mendiskriminasi penyelenggaraan pendidikan di madrasah. Di antara kebijakan pemerintah Hindia Belanda dalam 
VOLUME 14 NOMOR 1 TAHUN 2021

P-ISSN : 1979-9357

E-ISSN : 2620-5858

mengawasi pendidikan Islam adalah penerbitan Ordonansi Guru. Ordonansi mewajibkan setiap guru agama Islam untuk meminta dan memperoleh izin terlebih dahulu sebelum melaksanakan tugasnya sebagai guru agama. Dampak negatif yang dihasilkan ordonansi ini bisa digunakan untuk menekan Islam dan dikuatkan dengan alasan stabilitas keamanan. Hingga akhirnya pada tahun 1905 ordonansi dicabut karena tidak relevan lagi dan diganti dengan ordonansi tahun 1925 yang isinya hanya mewajibkan guru agama untuk memberi tahu saja bukan meminta izin (Daulay 2007, 35-36; Steenbrink 1991, 35).

b. Madrasah Tahun $1945-1974$

Setelah memasuki tahun 1945 kondisi negara Republik Indonesia tidak lagi dijajah oleh kolonial Belanda dan Jepang. Bangsa Indonesia sudah menjadi bangsa yang merdeka dan berdaulat. Pasca kemerdekaan, segala bentuk kebijakan terhadap pendidikan sudah ditentukan sendiri, termasuk penyelenggaraan madrasah. Salah satu bentuk kebijakan terhadap madrasah adalah pengumuman BPKNIP (Badan Pekerja Komite Nasional Indonesia Pusat) berdasarkan pada berita RI Tahun II No. 4 dan 5 hal. 20 kolom 1 bahwa: dalam memajukan pendidikan dan pengajaran di langgar-langgar dan madrasah berjalan terus dan diperpesat" (Asrohah 1999, 177) berdasarkan hal tersebut, kemudian keluarlah Surat Keputusan (SK) BP KNIP 27 Desember 1945 (agar madrasah mendapat bantuan dan perhatian dari pemerintah). Dalam laporan panitia penyelidik pengajaran RI tanggal 2 Mei 1946 yang diketua Ki Hajar Dewantara dengan 51 anggota juga disebutkan "pengajaran yang bersifat pondok pesantren dan madrasah dipandang perlu untuk diberi bantuan berupa biaya sesuai dengan keputusan BP KNIP" (Abdul Rachman Shaleh 2004, 22).

Selain itu, bentuk lain perhatian pemerintah terhadap madrasah adalah didirikan Departemen Agama pada tanggal 3 Januari 1946. Dalam perkembangannya, Departemen Agama intensif merperjuangkan politik pendidikan Islam di Indonesia dan tajam mengembangkan program-program perluasan dan peningkatan mutu madrasah (Maksum 1999, 123). Langkah pertama dilakukan Departamen Agama ketika itu adalah memberikan bantuan berupa pengadaan sarana dan prasarana serta biaya operasional, sebagaimana tertuang dalam Peraturan Menteri Nomor 1/1946 tanggal 19 Desember 1946. Kemudian tahun 1952, ketentuan tersebut disempurnakan melalui peraturan Menteri Agama Nomor 7/1952, yang menjelaskan tentang Jenjang Pendidikan, meliputi: a) Madrasah Rendah, dengan masa belajar 6 tahun; b) Madrasah Lanjutan Tingkat Pertama, dengan lama belajar 3 tahun setelah tamat Madrasah Rendah; c) Madrasah lanjutan Tingkat Atas dengan lama belajar 3 tahun setelah tamat Madrasah Lanjutan Tingkat Pertama (Rahim 2001, 54-55).

Pengakuan pemerintah terhadap madrasah sebagai lembaga pendidikan sudah diakui secara formal pada tahun 1950. Undang-Undang No. 4 Tahun 1950 tentang Dasar-Dasar Pendidikan dan Pengajaran di sekolah pada pasal 10 ayat (2) disebutkan "belajar di sekolah agama yang telah mendapat pengakuan 
VOLUME 14 NOMOR 1 TAHUN 2021

P-ISSN : 1979-9357

E-ISSN : 2620-5858

Departemen Agama, sudah dianggap memenuhi kewajiban belajar". Madrasah Wajib Belajar (MWB) dilaksanakan selama 8 tahun. Tujuan dari MWB diarahkan untuk pembangunan jiwa bangsa dalam bidang industri, ekonomi dan transmigrasi. Pertimbangan lainnya bahwa pada umur 6 tahun anak sudah berhak sekolah dan pada umur 15 tahun sesuai dengan undang-undang perburuhan yang berlaku anak telah diizinkan untuk mencari nafkah (Abdul Rachman Shaleh 2004, 26). Untuk dapat pengakuan Departemen Agama, madrasah harus memberikan pelajaran agama sebagai mata pelajaran pokok paling sedikit enam jam seminggu secara teratur di samping mata pelajaran umum.

Di samping itu, Departemen Agama juga melakukan penataan dan membina madrasah melalui penataan organisasi dan membuat "pilot proyek" yang dilakukan dengan cara penegerian sejumlah madrasah swasta. Penegerian pertama dilakukan terhadap madrasah ibtidaiyah, termasuk mengubah Sekolah Rakyat Islam (SRI) menjadi Madrasah Ibtidaiyah Negeri (MIN). Pada tahun 1967 dinegerikan Madrasah Tsanawiyah menjadi MTs.A.I.N sebanyak 182 buah sampai tahun 1970. Bersamaan pada tahun tersebut juga dinegerikan beberapa MA kemudian menjadi M.A.A.I.N, kemudian pada tahun 1970 proses penegerian dihentikan (Mohammad Kasim 2007, 42-56).

c. Madrasah Tahun $1975-1989$

Setelah mengalami perjalanan panjang dalam kondisi termarjinalisasi, pengelolaan pendidikan di madrasah berada di titik terang setelah memasuki tahun 1975. Hal ini dibuktikan dengan upaya penyetaraan madrasah yang dilakukan pemerintah sebagai bentuk sisdiknas yang integral. Merespon hal tersebut, Departemen Agama di bawah pimpinan Dr. Mukti Ali, M.A mengeluarkan SKB 3 Menteri No. 6 Tahun 1975, No. 037/U/1975 dan No.36 Tahun 1975 tentang Peningkatan Mutu Pendidikan Madrasah. Melalui SKB 3 menteri pendidikan madrasah diharapkan agar ijazah madrasah dapat mempunyai nilai yang sama dengan sekolah umum sederajat; lulusan madrasah dapat melanjutkan ke sekolah umum setingkat lebih atas; siswa setingkat madrasah dapat berpindah ke sekolah umum yang setingkat (Abdul Rachman Shaleh 2004, 29).

Semula madrasah negeri dan sekolah dinas lingkungan Departemen Agama mempunyai banyak bentuk dan jenis seperti MIN 358 buah, MTsAIN 182 buah, MAAIN 43 buah, PGA 4 tahun 146 buah, PGA 6 tahun 116 buah, PPUPA 3 buah, PHIN 1 buah dan SPIAIN 83 buah. Kemudian, melalui SK Menteri Agama dilakukan perubahan nama dan struktur menjadi MTsAIN dijadikan MTsN, MAAIN dijadikan MAN, PGA 4 tahun dijadikan MTsN, PGA 6 tahun dijadikan PGAN 3 tahun sesudah MTsN dan sebagaian menjadi MAN, PPUPA dijadikan MAN, PHIN dijadikan MAN, dan SPIAIN dijadikan MAN.

Dengan demikian, terjadi perubahan dan lokasi yang tidak merata menurut pertimbangan keperluan pendidikan bagi masyarakat dan lingkungannya sehingga setelah program restrukturisasi dilanjutkan dengan 
VOLUME 14 NOMOR 1 TAHUN 2021

P-ISSN : 1979-9357

E-ISSN : 2620-5858

relokasi. Pada masa ini, diputuskan tentang persyaratan untuk madrasah swasta. Mengenai madrasah swasta didasarkan atas SK Menteri Agama No.5 Tahun 1977 yang diartikan sebagai lembaga pendidikan yang menjadikan pelajaran agama Islam sebagai mata pelajaran dasar yang diberikan sekurangkurangnya 30\% di samping mata pelajaran umum dan diselenggarakan oleh organisasi, yayasan, badan atau perorangan sebagai pengurus atau pemiliknya (Abdul Rachman Shaleh 2004, 30).

Untuk mewadahi pengintegrasian pendidikan, baik umum maupun Islam, maka diterbitkan UU No. 2 Tahun 1989 yang memberi peluang dan kesempatan untuk mengembangkan pendidikan Islam. Hal ini dapat dilihat dari beberapa pasal sebagai berikut: Pasal 1 ayat 2 disebutkan bahwa pendidikan nasional adalah pendidikan yang berakar pada kebudayaan bangsa Indonesia dan berdasarkan pada Pancasila dan UUD 1945. Tidak bisa dipungkiri bahwa pendidikan Islam, baik sebagai sistem maupun institusinya merupakan warisan budaya bangsa yang berakar pada masyarakat bangsa Indonesia. Pasal 4 tentang tujuan pendidikan nasional yang bertujuan mencerdaskan kehidupan bangsa dan mengembangkan manusia Indonesia seutuhnya yaitu manusia yang beriman dan bertakwa terhadap Tuhan Yang Maha Esa dan berbudi pekerti luhur, memiliki pengetahuan dan keterampilan, kesehatan jasmani dan rohani, kepribadian yang mantap dan mandiri serta tanggung jawab kemasyarakatan dan kebangsaan. Pasal 11 ayat 1 disebutkan bahwa jenis pendidikan yang termasuk jalur pendidikan sekolah terdiri atas pendidikan umum, pendidikan kejuruan, pendidikan luar biasa, pendidikan kedinasan, pendidikan keagamaan, pendidikan akademik dan pendidikan profesional. Pasal 39 ayat 2 menyatakan isi kurikulum setiap jenis dan jalur serta jenjang pendidikan wajib memuat pendidikan pancasila, pendidikan agama dan pendidikan kewarganegaraan. Pasal 47 ayat 2 dinyatakan bahwa ciri khas satuan pendidikan yang diselenggarakan oleh masyarakat tetap diindahkan. Dengan pasal ini, satuan-satuan pendidikan Islam, baik yang berada di jalur sekolah maupun tidak akan tetap tumbuh dan berkembang secara terarah dan terpadu dalam sisdiknas.

Sejak diberlakukannya UU No. 2 Tahun 1989, pendidikan agama telah diwajibkan dari tingkat SD sampai dengan perguruan tinggi sehingga pendidikan madrasah memiliki urgensitas bagi pendidikan nasional. Sebelumnya kondisi madrasah termarjinalkan, berbeda setelah tahun 19751989, madrasah setara dalam sistem pendidikan nasional.

d. Madrasah Tahun 1990 - Sekarang

Fenomena madrasah pada 1990 masih menunjukkan besarnya perhatian pemerintah terhadap madrasah. Mengawali tahun tersebut pemerintah mengeluarkan PP No. 28 Tahun 1990 tentang Pendidikan Dasar, pasal 4 ayat 3 menegaskan bahwa SD dan SLTP yang berciri khas agama Islam yang diselenggarakan oleh Departemen Agama, masing-masing disebut Madrasah Ibtidaiyah (MI) dan Madrasah Tsanawiyah (MTs) (Rukiati and Hikmawati 2006, 75-76). 
Ketika era reformasi bergulir, maka peran tokoh pendidikan melakukan perubahan dan pembaharuan, di sektor pendidikan yaitu memperbaharuai UU pendidikan Tahun 1989 dan kurikulum 1994. Seiring dengan masuknya madrasah dalam sisdiknas, maka bantuan pinjaman dari negara-negara donor seperti Asian Development Bank (ADB), dan Islamic Development Bank (IDB) berdatangan. Melalui bantuan dari dana pinjaman tersebut, Departemen Agama mengembangkan madrasah model yang ditandai dengan dua ciri pertama memiliki berbagai keunggulan yang tidak dijumpai pada madrasah pada umumnya dan kedua memiliki kewajiban untuk membina dan meningkatkan madrasah lainnya. Sebagai madrasah unggulan, madrasah model ini memiliki beberapa ciri:

1) Memiliki fasilitas yang lengkap dan mewah.

2) Kurikulum plus yaitu kurikulum yang diturunkan dari visi dan misi lembaga.

3) Memiliki laboratorium yang lengkap untuk pembalajaran bahasa asing dan sain.

4) Memiliki perpustakaan dengan koleksi yang lengkap.

5) Memiliki guru yang di seleksi berdasarkan distinctive competencies.

6) Memiliki murid-murid pilihan berdasarkan penyeleksian yang ketat.

7) Memiliki waktu yang lebih panjang dari sekoah biasa karena ada kurikulum tambahan.

8) Menetapkan biaya yang cukup tinggi yang hanya dapat dijangkau oleh siswa dari latar belakang yang mampu.

9) Meningkatkan kesejahteraan guru dan staff.

10) Menggunakan model asrama.

Selain ciri-ciri di atas, madrasah model juga ditandai dengan perubahan paradigma sekolah biasa yang menganggap kelas adalah auditorium, namun di madrasah model adalah laboratorium (Nata 2010, 301-2). Salah satu contoh madrasah model ialah MAN Insan Cendikia (IC) Serpong dan Gorontalo. Awalnya, madrasah ini adalah SMU Insan Cendikia Serpong dan Gorontalo. Sekolah ini dibentuk oleh BJ. Habibie ketika ia menjabat Kepala Badan Pengkajian dan Penerapan Teknologi (BPPT) yang gelisah melihat rendahnya minat lulusan pesantren melanjutkan ke perguruan tinggi. Hingga akhirnya, pada tahun 1996 melalui penyetaraan ilmu pengetahuan dan teknologi lahirlah sekolah ini. Pada tahun 2000/2001, pengelolaannya dilimpahkan dari BPPT kepada Departemen Agama dan bertransformasi menjadi MAN Insan Cendikia tanpa mengurangi ciri khas dan sistem pembelajaran selama ini. Pada tahun 2006, MAN IC ditetapkan sebagai MA Program Khusus bertaraf Internasional oleh Dirjen Pendis Kemenag RI. Para siswa di madrasah ini setiap tahunnya hanya menerima 120 orang siswa dan mereka diberi beasiswa penuh. Madrasah ini menggunakan kurikulum KTSP dan Cambridge Universty. Madrasah ini bersifat asrama (Boarding school) dan memiliki fasilitas lengkap (Syafaat 2011, 41-42). Selain itu juga dibentuk madrasah terpadu yang terdiri dari tingkatan MIN, MTsN dan MAN dan berada dalam satu lokasi yang memiliki satu kesatuan kurikulum, 
administrasi dan manajemen diantaranya ialah Madrasah Terpadu Padang, Jojakarta, dan Aceh.

Di era globalisasi saat ini, telah bemunculan madrasah yang dikelola dengan manajemen coorporate yaitu pengelolaan yang ditujukan untuk memberikan pelayanan yang baik dan memuaskan kepada seluruh pelanggannya. Standarisasinya mulai dari tingkat Nasional seperti BAN-SM sampai tingkat Internasional ISO nilai akreditasinya pun mencapai nilai memuaskan (A atau A plus). Selanjutnya, melalui UU No. 23 Tahun 2003 tentang Sisdiknas, perkembangan dan kemajuan madrasah tampak lebih dinamis dan progresif karena UU ini semakin mempertegas pengakuan madrasah serta tersedianya anggaran pendidikan dari APBN melalui BOS (Nata 2010, 303).

Pada awal perkembangannya, madrasah didirikan atas kepedulian dan inisiatif dari para tokoh ulama dan masyarakat yang ingin meningkatkan kecerdasan masyarakat terhadap politik pendidikan Belanda, dan memurnikan serta mengokohkan akidah umat Islam dari sekulerisasi dan kristenisasi Belanda. Pendirian madrasah sebagian besar didanai melalui swadaya masyarakat yang berbentuk wakaf, infak, hibah, sumbangan rutin atau donatur tetap. Karena itu secara tidak langsung masyarakat dapat menyekolahkan anak-anaknya dengan biaya yang ringan.

Madrasah yang dulunya dipandang sebagai sekolah kelas dua dan terpinggirkan bahkan ironisnya sempat dikatakan sekolah liar karena masih belum dikategorikan sebagai lembaga pendidikan nasional meskipun ia lebih dahulu hadir di Indonesia. Madrasah yang dibangun dari, oleh dan untuk masyarakat memiliki ciri khas yang kental. Tidak berlebihan jika dikatakan bahwa madrasah adalah inspirator bagi pembentukan kurikulum-kurikulum di Indonesia. Sebut saja misalnya KTSP yang menciptakan kurikulum berbasis kebutuhan daerah setempat. Madrasah secara de facto telah terlebih dahulu menerapkan sistem ini. Lembaga pendidikan yang dibangun melalui swadaya masyarakat ini telah mengimplementasikan nilai-nilai kultural lokal sebagai dasar dalam PBM. Bahkan hingga kurikulum saat ini yang berbasis karakter, madrasah juga telah lama mengaplikasikan nilai karakter dalam pendidikan. Hal ini terbukti dengan nilai keikhlasan yang tinggi antara pendidik dan peserta didik. Para pendidik yang hanya digaji dengan seikhlasnya dan tidak jarang digaji hanya dengan hasil panen setahun sekali seperti beras, misalnya. Para peserta didik juga dituntut untuk menerapkan nilai-nilai budaya pendidikan Islam.

Sejalan dengan berbagai perkembangan dan perubahan paradigma dunia pendidikan saat ini, madrasah pun mengalami berbagai perubahan. Banyak faktor yang menyebabkannya. Keadaan sosial ekonomi masyarakat, pandangan keagamaan, motif sekulerisme, serta globalisasi, serta peran positif pemerintah di satu sisi menyebabkan dampak positif bagi madrasah yakni keberlangsungan madrasah semakin terjamin, namun juga berdampak negatif yaitu perhatian masyarakat agak berkurang kepada madrasah, sehingga madrasah tergantung dengan bantuan pemerintah. Karena itu, akhir-akhir ini kembali peran masyarakat tersebut digali melalui konsep 


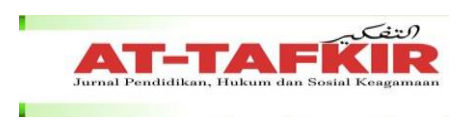

VOLUME 14 NOMOR I TAHUN 2021

P-ISSN : 1979-9357

E-ISSN : $2620-5858$

Manajemen Berbasis Madrasah (MBS). Dengan berbagai konsep tersebut ketergantungan masyarakat madrasah terhadap pemerintah diharapkan berkurang, mengingat mayoritas madrasah memang milik masyarakat. Partisipasi masyarakat yang menjadi kekuatan madrasah selama ini harus menjadi prioritas untuk dibangun dan dikembangkan kembali. Madrasah juga tidak sekedar meramaikan pentas dunia pendidikan. Namun juga diharapkan menjadi pioner dengan berbagai konsep madrasah unggulan.

\section{B. Madrasah Aliyah Dalam Sistem Pendidikan Nasional}

Sistem pendidikan Islam yang berlaku di Indonesia pada masa awal kemerdekaan adalah sesuai dengan apa yang diamanatkan dalam Undang-Undang No. 4 Tahun 1950. Dalam UU ini, ada sebuah upaya yang menjadi perhatian khusus pemerintah terhadap lembaga pendidikan madrasah yang dianggap sebagai sebuah lembaga yang memiliki peran yang sangat penting dalam meningkatkan ilmu pengetahuan bagi masyarakat di Indonesia. Kendati dalam UU tersebut tidak mewajibkan secara langsung pemberian mata pelajaran agama pada sekolah-sekolah umum, melainkan harus mendapatkan sebuah persetujuan dari wali siswa terlebih dahulu. Ini maknanya adalah bahwa para wali murid boleh memilih untuk anaknya dalam memberikan pelajaran agama kepada anak-anaknya.

Keluarnya Ketetapan MPRS No. II/MPRS/1960 tentang Garis-garis Besar Pola Pembangunan Nasional Semesta Berencana memberikan titik terang tentang status mata pelajaran agama dalam pendidikan umum. Melalui ketetapan MPRS ini dinyatakan bahwa mata pelajaran agama merupakan salah satu mata pelajaran yang wajib diberikan pada setiap sekolah-sekolah umum demi tercapainya tujuan pembangunan nasional yang dicanangkan tersebut. Departemen Agama diberikan mandat agar bersunguh-sungguh dalam menetapkan pendidikan agama di sekolah sampai pada perguruan tinggi. Pada tahap selanjutnya, pada masa orde baru dikeluarkan SKB 3 Menteri pada Tahun 1975 antara Departemen Agama, Departemen Pendidikan dan Kebudayaan, dan Departemen Dalam Negeri merupakan wujud dari keseriusan pihak pemerintahan untuk mengembangkan sistem pendidikan nasional dalam kaitannya lembaga pendidikan Islam sebagai respon terhadap Inpres No. 15 Tahun 1974. Semenjak dikeluarkan SKB 3 Menteri tersebut, banyak madrasahmadrasah yang ada di nusantara melakukan perubahan status menjadi negeri. Dengan demikian, peran negara dan masyarakat menjadi lebih kuat dalam melakukan kontrol terhadap keberlangsungan dan perkembangan madrasah-madrasah tersebut (Daulay 2004, 152).

Hasil dari kesepakatan 3 menteri dan untuk menindaklanjutinya lahirlah SKB 2 Menteri. Inti utama dari kebijakan ini adalah penyamaan lulusan sekolah dan madrasah. Madrasah dapat melanjutkan ke sekolah umum yang lebih tinggi. Alhasil lulusan madrasah aliyah dapat melanjutkan ke perguruan tinggi umum. Untuk menyamakan persepsi ini, lahirlah kurikulum tahun 1984. Pemberlakukannya di madrasah melalui Keputusan Menteri Agama Nomor 99, 100, dan 101 Tahun 1984, kurikulum madrasah semakin mempertegas integrasi kurikulum ke dalam system pendidikan nasional, sama dengan pendidikan di sekolah umum. Dengan kata lain, kurikulum madrasah sama dengan pendidikan di sekolah, tetapi kurikulum madrasah 
VOLUME 14 NOMOR 1 TAHUN 2021

P-ISSN : 1979-9357

E-ISSN : 2620-5858

masih menyelenggarakan muatan pendidikan agama, bahkan pada masa tersebut kurikulum agama lebih banyak dibandingkan kurikulum umum.

Tidak hanya sebatas itu, pemberdayaan madrasah terus berlanjut yang ditandai dengan munculnya Undang-Undang No. 2 Tahun 1989 tentang Sistem Pendidikan Nasional. Perubahan yang terjadi pada masa ini, madrasah muncul dengan predikat barunya sebagai pendidikan umum yang berciri khas agama Islam yang terdiri dari Madrasah Ibtidaiyah (MI), Madrasah Tsanawiyah (MTs), dan Madrasah Aliyah (MA). Menyahuti perubahan-perubahan ini, madrasah termasuk madrasah aliyah merubah kurikulum dengan perbandingan alokasi waktu 16-18\% untuk mata pelajaran agama dengan catatan alokasi waktu untuk pelajaran umum muatan nasional diberilakukan $100 \%$ sama dengan sekolah umum.

Upaya peningkatan mutu pendidikan mencapai puncaknya ketika lahir Undang-Undang tentang Sistem Pendidikan Nasional (UU Sisdiknas) Nomor 20 Tahun 2003. Persoalan penting yang menjadi sorotan dalam UU Sisdiknas ini adalah penyamaan posisi pendidikan di sekolah dengan madrasah. Pemerintah tidak lagi membuat kebijakan dualisme pendidikan atau pensubordinasian madrasah. Madrasah dijadikan sebagai bagian dari pendidikan nasional. Dengan demikian, tujuan madrasah juga harus mengikuti tujuan pendidikan nasional. Secara kelembagaan Madrasah Aliyah (MA) sama dengan Sekolah Mengenah Atas (SMA), namun tetap dalam pengelolaan Departemen Agama dan sistem kurikulum tetap mempertahankan ciri madrasah.

Perubahan yang sangat signifikan terhadap penyelenggaraan madrasah aliyah ketika pemerintah memberlakukan Undang-Undang Nomor 22 Tahun 1999 tentang Pemerintah Daerah, kemudian direvisi dengan Undang-Undang Nomor 32 Tahun 2004. Perubahan yang terjadi di bidang pendidikan adalah tanggung jawab terhadap penyelenggaraan pendidikan. Jika sebelumnya pengelolaan pendidikan bersifat sentralisasi, setelah diberilakukan undang-undnag tersebut, pengelolaan pendidikan berlaku secara desentralisasi. Dengan kata lain, pendidikan tidak lagi dikelola oleh pemerintah pusat, tetapi sudah dilimpahkan kepada pemerintah daerah. Pemerintah daerah bertanggung jawab terhadap pengelolaan pendidikan.

Perubahan aturan tentang pemerintah daerah tersebut, banyak kalangan mengatakan awal dari kemajuan pendidikan dan demokrasi (Tilaar 2009, 286) pendidikan. Berbeda dengan sebelumnya pendidikan dipahami sebagai bentuk domestifikasi yaitu proses pendidikan yang dilakukan melalui proses penjinakan, pusat tidak perlu mengetahui apa kebutuhan peserta didik dan bagaimana kondisi sosialnya, yang terpenting harus mengikuti system yang dirumuskan dipusat meskipun itu tidak sesuai dengan kondisi anak didik (Tilaar 2009, 146). Namun fenomena tersebut berbeda yang dirasakan pendidikan di madrasah, termasuk madrasah aliyah. Pengelolaan pendidikan di madrasah aliyah dipahami sebagai bagian dari agama yang tidak didesentralisasikan, sehingga pengelolaan madrsah aliyah masih berada di bawah tanggung jawab dan wewenang pemerintah pusat.

\section{Peran Pemerintah Dalam Pengelolaan Madrasah}

Berbicara mengenai peran pemerintah terhadap madrasah sama juga membicarakan bagaimana pemerintah sebagai kelompok politik berinteraksi dengan kelompok kependidikan (educational groups). Relasi antara politik dan pendidikan 
VOLUME 14 NOMOR 1 TAHUN 2021

P-ISSN : 1979-9357

E-ISSN : 2620-5858

melahirkan sejumlah gesekan taktis dan strategis, terutama di kalangan pemerintah dan unit masyarakat yang bersangkut-paut dengan kepentingan politik dan edukasinya. Fenomena tersebut didasari oleh asumsi dasar bahwa pemerintah senantiasa melahirkan kebijakan yang dapat mengukuhkan legitimasi kekuasaannya. Atas dasar itu, negara akan selalu mengadakan kontrol terhadap kebijakan publik tersebut, baik pada tataran perumusan maupun pada tataran penetapan dan aplikasinya.

Madrasah merupakan lembaga pendidikan Islam yang memadukan bentuk klasikal dengan bentuk modern. Kehadiran madrasah sebagai lembaga pendidikan tidak berbeda dengan pendidikan lainnya, di mana sama-sama berada dalam kondisi dan situasi perpolitikan suatu negara (pemerintah). Dengan demikian, kemajuan dan kemunduran madrasah tidak terlepas dari peran pemerintah setempat dalam memberikan kebijakan dan perundang-undangan dalam pengelolaannya. Untuk melihat bukti adanya peran pemerintah dalam pengelolaan madrasah, biasanya dilihat pada empat aspek, yaitu pendanaan, sarana dan prasaran, kurikulum, dan sumber daya manusia.

Masa awal terbentuk madrasah atau masa kolonial Belanda merupakan masa dianggap kurang menguntungkan. Hal ini disebabkan kondisi perpolitikan Indonesia masih berada dalam pengaruh kolonial Belanda. Memang pada masa ini, madrasah sempat berkembang pesat, khususnya di Jawa, sehingga hal tersebut membuat resah Hindia Belanda sampai harus mengeluarkan peraturan menetapkan madrasah sebagai "sekolah liar". Kemudian, disusun oleh peraturan-peraturan pelarangan atas berdirinya madrasah dan menekan berkembangnya madrasah di nusantara (Fatchurrochman 2012, 22). Selain itu, pemerintah Belanda juga menerbitkan ordinasi guru, yaitu bentuk kebijakan yang mengharuskan guru-guru memiliki izin dari pemerintah Belanda.

Fenomena tersebut menunjukkan bahwa madrasah sangat jauh dari peran dan kebijakan pemerintah sendiri. Bukti lain, tidak adanya peran pemerintah terhadap madrasah di masa awal terlihat dari aspek pengelolaannya. Pada masa tersebut, madrasah dikelola berdasarkan inisiatif pendiri madrasah, sehingga tidak ada keseragaman dalam pelaksanaannya dan pengelolaannya. Misal, madrasah diniyah bentuk pendidikan yang sejalan dengan tawaran pembaharuan, madrasah Adabiyah lebih merupakan sekolah Belanda yang ditambah dengan materi agama, sedangkan Diniyah Zainuddin Labai lebih bersifat Islami ketimbang pendidikan modern (Maksum 1999, 103). Keanekaragaman pengelolaan tiap-tiap madrasah yang disebutkan menujukkan bahwa madrasah pada saat itu murni kebijakan pendiri.

Setelah merdeka, Indonesia menjadi sebuah negara yang berdaulat dalam pemerintahan sendiri. Dilihat dari masa perpolitikan Indonesia, masa ini disebut dengan orde lama, yaitu masa kepresidenan dijabat oleh Soekarno. Sebagai sebuah negara yang baru bangkit dari keterpurukan penjajah, tentu banyak aspek yang perlu dilakukan pembenahan, salah satunya adalah sistem pendidikan Islam yang sebelumnya oleh penjajah dianggap sebagai pendidikan yang harus dibatasi, baik dari pelaksanaannya maupun perkembangannya. Fenomena tersebut dapat dikatakan sebagai fenomena awal pertumbuhan pendidikan. Haidar Putra Daulay mengklasifikasikan periode ini sebagai fase pencarian bentuk pendidikan Islam 
VOLUME 14 NOMOR I TAHUN 2021

P-ISSN : 1979-9357

E-ISSN : 2620-5858

(Daulay 2004, 10). Artinya, di mana pendidikan mencari format untuk penyelenggaraan, baik dari aspek kelembagaan, kurikulum, serta manajemen.

Peran pemerintah orde lama terhadap madrasah dibuktikan dengan munculnya berbagai peraturan dan perundang-undangan yang mengatur madrasah, baik dari segi pendanaan, kurikulum, sumber daya manusia, dan sarana -prasarana. Sebagai bentuk awal dari peralihan masa kolonial ke masa kemerdekaan, tentu peran pemerintah dalam pengelolaan madrasah belum dapat dikatakan maksimal. Persoalan politik yang belum pulih benar sebagai akibat dari kolonial Belanda dan Jepang menjadikan pemerintah Indonesia untuk terus melakukan pembenahan. Berada dalam anomalisasi ini tentu pemerintah dituntut untuk melakukan pembenahan dalam skala prioritas. Namun demikian, bukan berarti masa orde lama tidak ada peran pemerintah dalam memajukan madrasah. Banyak hal yang dilakukan pemerintah dalam memajukan madrasah, walaupun tidak dikatakan maksimal, namun dapat disebutkan sebagai awal peran pemerintah dalam pengelolaan madrasah di Indonesia, baik dalam bentuk pendanaan, kurikulum, sumber daya manusia dan saranaprasarana.

Bukti konkrit peran pemerintah dalam pendanaan madrasah masa orde lama adalah anjuran Badan Pekerja Komite Nasional Pusat (BPKNP), yang menyebutkan bahwa madrasah dan pesantren yang pada hakikatnya adalah satu alat dan pencerdasan rakyat jelata yang sudah mengakar dalam masyarakat Indonesia pada umumnya, hendaklah pula mendapat perhatian dan bantuan nyata tuntutan dan bantuan material dari pemerintah (Zulhandra 2009, 345).

Kebijakan tersebut baru terealisasi setelah ketika Departemen Agama didirikan. Lembaga ini resmi berdiri pada Tanggal 3 Januari 1946. Sejak didirikan lembaga ini yang secara intensif memperjuangkan pendidikan Islam di Indonesia, termasuk dalam hal ini madrasah. Salah satu yang menjadi orientasi Departemen Agama dalam bidang pendidikan Islam, seperti madrasah, pesantren, dan mengurus pendidikan agama di sekolah-sekolah umum (Daulay 2004, 53). Perlu dicatat bahwa kehadiran Departemen Agama dapat dikatakan sebagai awal kemajuan dan kecemerlangan madrasah, sekaligus sebagai bentuk perhatian pemerintah dalam upaya meningkat kemajuan madrasah di awal kemerdekaan. Sebagai bentuk realisasi upaya tersebut, pemerintah melalui Departemen Agama memberikan perhatian dan peran terhadap madrasah melalui kebijakan dan perundang-undangan yang mencakup dalam bagian pendanaan, kurikulum, sumber daya manusia dan saranaprasarana.

Pendanaan yang dimaksud di atas berupa pemberian bantuan pada madrasah yang diberikan setiap tahun dengan perhitungan perkapita @ Rp. 60 per-murid (uang lama) (Abdul Rachman Shaleh 2004, 22), didasarkan pada Peraturan Menteri Agama No. 1 Tahun 1946, tanggal 19 Desember 1946 tentang Pemberian Bantuan Madrasah. Meskipun pengalokasian dana bantuan untuk madrasah tidak merata, hanya beberapa keresidenan, seperti Daerah Istimewa Yogyakarta, Jakarta, dan Surakarta (Rahim 2001, 53-54). Namun hal ini merupakan awal langkah baik pemerintah orde lama dalam penyelenggaran madrasah. Di samping itu, dalam rangka memberikan motivasi kepada madrasah untuk meningkatkan kualitas akademiknya, pemerintah juga memberikan bantuan finansial. Pada tahun 1960-an, Departemen Agama memberikan subsidi kepada madrasah lokal sebesar Rp 10,- per murid, tetapi untuk 
VOLUME 14 NOMOR 1 TAHUN 2021

P-ISSN : 1979-9357

E-ISSN : 2620-5858

madrasah yang berafiliasi dengan organisasi berskala nasional subsidi dinaikkan menjadi tidak kurang dari Rp 30,- setiap murid. Kebijakan ini mempunyai dampak terhadap pertambahan jumlah madrasah. Pemberian bantuan ini didasarkan kepada Peraturan Menteri Agama RI Nomor 2 Tahun 1960.

Sedangkan peran pemerintah orde lama dalam pengadaan sarana dan prasarana sebagai wujud kepedulian terhadap madrasah dibuktikan dengan membangun madrasah di berbagai daerah di Indonesia. Buktinya, sampai pertengahan dekade 60-an, madrasah telah hadir di berbagai daerah di hampir seluruh propinsi di Indonesia. Menurut laporan, jumlah madrasah tingkat rendah (MI) mencapai 13.057, tingkat pertama (Tsanawiyah) mencapai 776 buah, dan tingkat menengah (Aliyah) 16 buah. Jadi, total keseluruhan madrasah masa ini mencapai 13.849 (Maksum 1999, 126). Angka penyebaran madrasah ini menunjukkan bahwa pemerintah orde lama melalui Departemen Agama sangat memperhatikan penyelenggaraan dan kemajuan madrasah. Selain itu, bentuk bantuan yang diberikan sebagaimana tercantum dalam Peraturan Menteri Agama RI No. 1 Tahun 1946, salah satunya adalah membeli alatalat pelajaran, membiaya administrasi, dan memelihara ruang-ruang dan gedunggedung madrasah (Rahim 2001, 56).

Terkait dengan persoalan kurikulum, pada mulanya pemerintah orde lama kurang memperhatikan kurikulum madrasah. Kurikulum madrasah pada masa itu belum muncul secara nasional. Praktis kurikulum madrasah masih ditentukan oleh lembaga madrasah masing-masing, tentunya terjadi perbedaan antara satu dan lainnya. Pada saat itu pun, namanya bukan kurikulum melainkan rencana pelajaran (Kelly 2004, 46). Seperti rencana pelajaran Madrasah Mu'allimin Muhammadiyah Yogyakarta tahun 1959, berbeda dengan rencana pelajaran Pondok Pesantren Modern Gontor Ponorogo Jawa Timur tahun 1958 yang di dalamnya ada KMI (Kulliatul Mu'allimin al-Islamiyah), berbeda pula dengan rencana pelajaran Sekolah Guru P.U.I 6 Tahun 1958. Tampak bahwa, berbeda pula dengan madrasah-madrasah lain yang muncul saat itu. Perbedaan tersebut juga digambarkan secara perbandingan oleh Sumardi dalam Haidar Putra Daulay dengan: 30:70, 40:60, 50:50, 60:40, dan 70:30 dalam persentase (Daulay 2004, 53).

Pada tahun 1950, di mana kedaulatan Indonesia telah pulih untuk seluruh Indonesia, rencana pendidikan agama untuk seluruh wilayah Indonesia makin disempurnakan dengan dibentuknya panitia bersama yang dipimpin Mahmud Yunus dari Departemen Agama, Mr. Hadi dari Departemen Pendidikan dan Kebudayaan. Hasil dari panitia itu adalah SKB yang dikeluarkan pada bulan Januari. Keputusan ini secara umum mengklasifikasikan kurikulum berdasarkan jenjang pendidikan:

1) Pendidikan agama yang diberikan mulai kelas IV Sekolah Rakyat.

2) Di daerah-daerah yang masyarakat agamanya kuat, pendidikan agama diberikan mulai kelas I SR dengan catatan bahwa pengetahuan umumnya tidak boleh berkurang dibandingkan dengan sekolah lain yang pendidikan agamanya diberikan mulai kelas IV.

3) Di sekolah Lanjutan Pertama dan Tingkat Atas (umum dan kejuruan) diberikan pendidikan agama sebanyak 2 jam seminggu.

4) Pendidikan agama diberikan kepada murid-murid sedikitnya 10 orang dalam satu kelas dan mendapat izin dari orang tua / walinya. 
VOLUME 14 NOMOR I TAHUN 2021

P-ISSN : 1979-9357

E-ISSN : 2620-5858

5) Pengangkatan guru agama, biaya pendidikan agama, dan materi pendidikan agama ditanggung oleh Departemen Agama (Abdul Rahman Shaleh 2005, 26).

Persoalan yang dianggap penting setelah tahun 1950 adalah upaya pergantian kurikulum nasional. Pada tahun 1952 tercatat muncul kurikulum 1952 yang terkenal dengan nama Rentjana Pelajaran Terurai. Kurikulum ini sudah mengarah pada suatu sistem pendidikan nasional (dalam sistem persekolahan, artinya di luar madrasah, adapun madrasah ketika itu belum masuk pada sistem pendidikan nasional). Kemudian tahun 1964, pemerintah menyempurnakan kurikulum nasional dengan nama Rentjana Pendidikan 1964. Dari kurikulum ini, pemerintah mempunyai keinginan agar rakyat mempunyai pengetahuan akademik untuk pembekalan pada jenjang SD, sehingga pembelajaran dipusatkan pada program Pancawardhana, yaitu pengembangan moral, kecerdasan, emosional/artistik, keterampilan dan jasmani. Selanjutnya, kurikulum 1964 baru terjadi perubahan dengan datangnya kurikulum 1968.

Kurikulum 1968 merupakan pembaharuan dari Kurikulum 1964, yaitu dilakukannya perubahan struktur kurikulum pendidikan dari Pancawardhana menjadi pembinaan jiwa pancasila, pengetahuan dasar, dan kecakapan khusus. Kurikulum 1968 merupakan perwujudan dari perubahan orientasi pada pelaksanaan UUD 1945 secara murni dan konsekuen. Dari segi tujuan pendidikan, Kurikulum 1968 bertujuan bahwa pendidikan ditekankan pada upaya untuk membentuk manusia Pancasila sejati, kuat, dan sehat jasmani, mempertinggi kecerdasan dan keterampilan jasmani, moral, budi pekerti, dan keyakinan beragama. Isi pendidikan diarahkan pada kegiatan mempertinggi kecerdasan dan keterampilan, serta mengembangkan fisik yang sehat dan kuat.

Dalam peningkatan sumber daya manusia, peran pemerintah orde lama melalui perpanjangan tangan Departemen Agama menyiapkan tenaga pengajar yang masih dianggap kurang dalam pengembangan madrasah. Langkah-langkah yang ditempuh terkait dengan persoalan ini adalah. Pertama, Jangka Pendek, yaitu dengan menyelenggarakan pendidikan/kursus singkat. Kedua, Jangka Panjang, yaitu membuka/mendirikan pendidikan khusus yang menyiapkan calon guru agama, yaitu pada tanggal 16 Mei 1948 di Solo didirikan Sekolah Guru dan Hakim Agama Islam (SGHA). Sekolah ini kemudian dipindahkan di Yogyakarta tanggal 8 Desembar 1948. Karena agresi Belanda kedua, sekolah ini terhenti dan baru tanggal 16 Januari 1950 dibuka Kembali. Di samping itu, masa orde lama juga didirikan dan dikembangkan Pendidikan Guru Agama dan Pendidikan Hakim Islam Negeri. Kedua madrasah ini menandai perkembangan yang sangat penting di mana madrasah bertujuan mencetak tenaga-tenaga profesional keagamaan (Maksum 1999, 124).

Setelah terjadi peralihan masa kepemerintahan Indonesia tanggal 11 Maret 1966 dari Presiden Soekarno ke Presiden Soeharto atau dari masa orde lama ke orde baru membawa konsekuensi perubahan strategi politik dan kebijakan pendidikan nasional. Ada beberapa bentuk perubahan pada masa orde baru, yaitu sikap mental positif untuk menghentikan dan mengoreksi segala bentuk penyelewengan terhadap pancasila dan UUD 1945, mempertinggi kecerdasan dan ketrampilan, serta membina dan mengembangkan fisik yang kuat dan sehat.

Periode ini menandai munculnya awal pemerintahan orde baru yang bertekad untuk melaksanakan UUD (Undang-Undang Dasar) 1945 dan Pancasila secara murni 
VOLUME 14 NOMOR 1 TAHUN 2021

P-ISSN : 1979-9357

E-ISSN : 2620-5858

dan konsekwen. Dalam GBHN (Garis-garis Besar Haluan Negara) tahun 1993 ditegaskan dengan jelas bahwa sasaran pembangunan jangka panjang di bidang agama ialah terbinanya iman bangsa Indonesia kepada Tuhan Yang Maha Esa, dalam kehidupan yang selaras, seimbang, serasi antara lahiriah dan rohaniah, mempunyai jiwa yang dinamis dan semangat gotong-royong sehingga bangsa Indonesia sanggup meneruskan perjuangan untuk mencapai cita-cita tujuan nasional.

Pada awalnya, terkait peran pemerintah orde baru terhadap madrasah dapat dikatakan hanya melanjutkan tradisi dan kebijakan sebelumnya. Namun pada tahap berikutnya, antara akhir 70-an sampai akhir 80-an, pemerintah mulai memikirkan mengintegrasikan madrasah dalam sistem pendidikan nasional (Maksum 1999, 132). Langkah dilakukan dalam hal ini, pemerintah orde baru memperkuat posisi madrasah dalam setiap jenjang agar dapat menempati posisi yang sama dengan pendidikan, terutama dalam lanjutan bagi lulusan madsarah. Sebelumnya madrasah tidak bisa melanjutkan keperguruan tinggi umum, hanya sebatas perguruan tinggi agama, begitu juga dalam persoalan kerja, hanya dikalangan instansi agama.

Pendanaan madrasah pada orde baru awalnya tidak berbeda dengan masa orde lama. Masa ini dapat disebutkan sebagai bentuk melanjutkan kebijakan-kebijakan sebelumnya. Namun setelah banyak madrasah yang dinegerikan, pendapat madrasah jelas disebutkan menjadi tanggung jawab pemerintah orde baru. Hal ini sebagaimana disebutkan dalam Ketetapan MPRS No. XXVII/1966, pada tahun 1967 Menteri Agama mengeluarkan kebijakan untuk menegerikan sejumlah madrasah dalam semua tingkatan mulai dari tingkat Ibtidaiyah sampai dengan Aliyah. Melalui usaha ini, sebanyak 123 Madrasah Ibtidaiyah telah dinegerikan sehingga menambah jumlah total Madrasah Ibtidaiyah Negeri (MIN) menjadi 358. Dalam waktu yang bersamaan, juga telah berdiri sekitar 182 Madrasah Tsanawiyah Negeri dan 42 Madrasah Aliyah Agama Islam Negeri (MAAIN). Dengan memberikan status negeri ini, tanggung jawab pengelolaan memang menjadi beban pemerintah, tetapi pengaturan dan kontrol atas madrasah-madrasah itu menjadi lebih efektif (Maksum 1999, 141). Pengaturan dan kontrol yang dimaksudkan merupakan bentuk tanggung jawab dalam bentuk pembiayaan dan perlengkapan sarana dan prasarana madrasah.

Selain ketetapan di atas, setelah dikeluarkan SKB tiga Menteri tahun 1975 semakin memperjelas peran pemerintah dalam penyediaan sarana dan prasarana pada madrasah. Hal ini sebagaimana dikatakan oleh Haidar Putra Daulay, dengan dilaksanakannya SKB tiga Menteri ini berarti a) Eksistensi madrasah sebagai lembaga pendidikan Islam lebih mantap dan kuat; b) Pengetahuan umum pada madrasahmadrasah lebih meningkat; c) Fasilitas fisik dan peralatan lebih disempurnakan; c) Adanya civil effect terhadap ijazah madrasah (Daulay 2004, 152). Fasilitas fisik dan penyempurnaan peralatan madrasah sebagai sebuah gambaran bahwa pemerintah orde baru sangat berperan dalam pengembangan dan kemajuan madrasah.

Di samping itu, SKB tiga Menteri juga menjelaskan peran pemerintah orde baru dalam pengembangan dan perumusan kurikulum madrasah. Hal ini dikarenakan SKB ini dipandang sebagai pengakuan yang nyata terhadap eksistensi madrasah dan sekaligus langkah strategis menuju tahapan integrasi madrasah ke dalam sistem pendidikan nasional yang tuntas (Maksum 1999, 151). Salah satu bagian dari tahapan strategis yang dimaksud adalah penyempurnaan kurikulum pada madrasah. Persamaan status madrasah dengan sekolah tidak hanya tampak pada struktur 
VOLUME 14 NOMOR 1 TAHUN 2021

P-ISSN : 1979-9357

E-ISSN : 2620-5858

kelembagaan, tetapi juga dalam struktur mata pelajaran yang mengakomodasi secara penuh kurikulum sekolah (Departemen Agama RI 2001, 27).

Terkait SKB, penyempurnaan kurikulum madrasah merupakan langkah strategis dan esensial dalam merealisasikan SKB. Persamaan status madrasah dengan sekolah tidak hanya tampak pada struktur kelembagaan, tetapi juga dalam struktur mata pelajaran yang mengakomodasi secara penuh kurikulum sekolah. Dampaknya adalah terjadinya mobilitas sosial dan vertikal siswa-siswi madrasah yang selama ini terbatas di lembaga-lembaga tradisional (madrasah dan pesantren) dan berbarengan dengan itu; membuka peluang dan kemungkinan anak-anak santri memasuki wilayah pekerjaan pada sektor modern (Departemen Agama RI 2001, 27). Cukup banyak keuntungan SKB, tetapi hal itu tidak berarti menafikan kelemahan yang ada dari SKB. Alumni madrasah aliyah tidak siap untuk memasuki dunia pendidikan IAIN karena hanya berbekal kurang lebih 30\% pelajaran agama di MA. Untuk mengantisipasi keadaan seperti ini, selanjutnya Menteri Agama Munawir Sjadzali menggagas Madrasah Aliyah Program Khusus (MAPK), dalam rangka mengatasi krisis ulama. Adanya penyebutan dalam SKB bahwa mata pelajaran agama di madrasah kurang lebih $30 \%$, berarti yang $70 \%$ adalah mata pelajaran umum merupakan bentuk pergeseran dominasi muatan agama menjadi dominasi muatan umum dalam isi kurikulum MA, adalah syarat dengan muatan politis. Karena hal ini yang akan menggiring sistem pendidikan di Indonesia dari dualistik menjadi satu sistem pendidikan nasional.

Setelah SKB, Departemen Agama menyusun kurikulum 1976 (Abdul Rachman Shaleh 2004, 34), Keputusan Menteri Agama No. 75, tanggal 29 Desember 1976 dalam rangka penyempurnaan kurikulum madrasah aliyah tahun 1976, diberlakukan secara intensif mulai tahun 1978 (Ahid 2013, 124). Kemudian kurikulum 1976 ini disempurnakan lagi melalui kurikulum 1984 sebagaimana dinyatakan dalam SK Menteri Agama No. 45 T ahun 1987 (Muhaimin 2005, 197). Nampak di sini bahwa isi mata pelajaran umum kurikulum madrasah harus mengikuti kurikulum sekolah, dengan alasan agar supaya lembaga pendidikan madrasah diakui sebagai suatu sistem pendidikan nasional. Ini cukup politis, tetapi walaupun demikian, lembaga madrasah tetap mempertahankan ciri khas ke-Islamannya, terbukti dengan bergantinya kurikulum dari Depdikbud, yang selanjutnya diikuti oleh madrasah, Menteri Agama selalu mengeluarkan keputusannya (KMA) dalam rangka menyikapi pergantian kurikulum tersebut. Dan KMA itu berisi tentang desain kurikulum madrasah yang baru dengan substansi senantiasa mempertahankan ciri khas ke-Islamannya yang tergambar dalam muatan pelajaran agama.

Selain peran kurikulum, persoalan sumber daya manusia juga menjadi bagian perhatian pemerintah orde baru dalam penyelenggaraan madrasah. Hal ini dibuktikan dengan upaya pemerintah membekali siswa MA dengan berbagai pengetahuan agar dapat mengimbangi pendidikan umum, sekaligus membekali siswa agar dapat melanjutkan keperguruan tinggi umum. Sebelumnya alumni madrasah hanya dapat melanjutkan ke perguruan tinggi Islam dan bekerja pada instansi Islam. Namun setelah dirumuskannya SKB tiga Menteri, alumni madrasah dapat melanjutkan ke perguruan tinggi umum dan bekerja pada instansi non-agama.

Setelah bergantinya masa orde baru kemudian digantikan dengan masa refomasi, banyak perubahan dan pembaharuan pendidikan Islam, khususnya 
madrasah. Hal ini menunjukkan bahwa pemerintah reformasi lebih agresif menangani persoalan madrasah. Meskipun demikian, banyak kritikan terhadap kebijakan era ini yang ditujukan oleh berbagai pihak pemerhati madrasah. Proses perubahan sistem desentralisasi menggantikan sistem sentralisasi yang didasari UU Nomor 22 Tahun 1999 tentang Pemerintahan Daerah dan UU Nomor 25 Tahun 2000 tentang Perimbangan Keuangan Pusat dan Daerah menyebabkan madrasah didiskriminasikan.

Ada persoalan yang dianggap diskrimitaf pada periode ini, dilema yang dirasakan madrasah dari perubahan kebijakan dan perundang-undangan di atas. Penentuan otonomi daerah yang diundangkan tahun 1999 membawa implikasi kurang baik terhadap penyelenggaraan pendidikan Islam. Peralihan sistem sentralisasi kepada desentralisasi tidak berdampak baik terhadap madrasah. Kesan yang timbul, pemberian otonomi daerah menjadi tantangan baru dalam pengelolaan madrasah. Sebelumnya, secara kelembagaan sudah dianggap sama dengan posisi sekolah umum, namun dalam pengelolaan pendidikan belum dianggap bagian dari pendidikan yang ada di daerah sehingga pendanaan madrasah harus menunggu dari kebijakan pusat melalui perpanjangan tangan Kementerian Agama daerah. Implikasinya, pemerintah daerah merasa tidak pertanggung jawab terhadap pengelolaan madrasah sehingga madrasah tidak dianggap sebagai bagian dari pendidikan yang ada di daerah tersebut.

Memang agak terkesan ambigu penentuan madrasah dalam sistem disentralisasi. Di satu sisi, pemerintah memberi hak penyelenggaraan pendidikan pada pemerintah daerah. Namun di sisi lain, pemerintah memberlakukan sentralisasi pada persoalan agama. Kesan ambiguitas ini kemudian direspon oleh Ali Anwar bahwa pada masa reformasi ini telah terjadi perubahan dari sistem pemerintahan yang bercorak sentralistik menuju desentralistik. Hal ini ditandai dengan UU RI No. 22 Tahun 1999 tentang Pemerintah Daerah. Pasal 7 ayat (l) UU RI No. 22 Tahun 1999 menyatakan bahwa agama merupakan salah satu urusan yang tidak diselenggarakan oleh pemerintah daerah. Di sisi lain, pendidikan, menurut pasal 11 ayat (2) UU RI No. 22 Tahun 1999 merupakan urusan wajib yang menjadi kewenangan pemerintah daerah. Madrasah, yang menurut UU Sisdiknas No. 2 Tahun 1989 didefinisikan sebagai sekolah umum yang berciri khas Islam, dapat diperdebatkan, apakah ia bagian dari agama ataukah Pendidikan (Anwar 2010, 49). Jika madrasah dianggap sebagai lembaga pendidikan berarti keberadaannya mendapat hak dari pemerintah daerah.

Selain itu, menanggapi UU Nomor 22 Tahun 1999 terkait dengan posisi madrasah, semakin dipertegas lagi oleh Menteri Agama dalam surat yang ditujukan kepada Menteri Dalam Negeri No. MA/402/2000 pada tanggal 21 November 2000, yang isinya:

Bahwa kewenangan penyelenggaraan pendidikan agama pada sekolah umum dan penyelenggaraan Madrasah Ibtidaiyah, Madrasah Tsanawiyah, dan Madrasah Aliyah diserahkan kepada daerah kabupaten/kota sesuai dengan asas desentralisasi pemerintah yang meliputi aspek-aspek operasional penyelenggaraan; penjabaran kurikulum; penyediaan tenaga dan kependidikan; penyediaan sarana dan prasarana; penyediaan anggaran (Abdul Rachman Shaleh 2004, 146). 
VOLUME 14 NOMOR 1 TAHUN 2021

P-ISSN : 1979-9357

E-ISSN : 2620-5858

Namun realitanya, surat yang disampaikan tersebut tidak ada tanggapan sehingga sampai sekarang sikap acuh pemerintah daerah terhadap penyelenggaran madrasah masih terlihat. Untuk tidak menjadi masalah, terutama terhadap mutu dan pemerataan yang lebih luas dan nyata, pemanfaatan personalia dan mobilitas lulusan, tentunya pembinaan madrasah yang tetap sentralistik namun disertai pelimpahan wewenang di daerah dalam bentuknya sebagai dekonsentrasi, yaitu pelimpahan wewenang dari pemerintah (Departemen Agama/Gubernur sebagai wakil daerah atau perangkat pusat di daerah/Kanwil) (Abdul Rachman Shaleh 2004, 147).

Kejelasan posisi madrasah dari segi kurikulum baru terlihat kemudian setelah disahkannya UU Sisdiknas No. 20 Tahun 2003. Kurikulum 2004 yang diilhami oleh UU Sisdiknas No. 20 Tahun 2003, dalam pasal 36 dan 38, disebutkan bahwa kurikulum dikembangkan dengan mengacu pada standar nasional pendidikan untuk mewujudkan tujuan pendidikan nasional, dengan prinsip sesuai dengan satuan pendidikan, potensi daerah dan peserta didik. Kerangka dasar dan struktur kurikulum pendidikan dasar dan menengah ditetapkan oleh pemerintah. Melihat realitas yang demikian madrasah juga harus bersikap, dengan tetap mempertahankan ciri khas ke-Islamannya.

Dari penjabaran di atas, dapat dipahami bahwa setelah disahkan UU Sisdiknas Nomor 20 Tahun 2003, penyelenggaraan madrasah tidak menjadi persoalan lagi terutama masalah pendanaan yang selama ini dikeluhkan oleh penyelenggara. Sebab UU Sisdiknas Nomor 20 Tahun 2003 dengan jelas menyebutkan pada pasal 15 bahwa jenis pendidikan mencakup pendidikan umum, kejuruan, akademik, profesi, vokasi, keagamaan, dan khusus. Kemudian dipertegas lagi pada pasal 17 dan 18 pada penyebutan sekolah dasar dan menengah. Dalam hal ini, sekolah dasar yang dimaksud adalah SD dan MI, begitu juga sekolah menengah yang dimaksud adalah SMP dan MTs - SMA dan MA. Uraian tersebut semakin mempertegas posisi madrasah dalam sistem pendidikan Nasional. Dengan demikian, madrasah tidak lagi dipandang sebagai lembaga pendidikan yang didiskriminasikan.

\section{KESIMPULAN}

Dalam arus dinamika yang terjadi mulai di zaman klasik Islam hingga era reformasi, madrasah senantiasa hadir memberikan respon yang jelas melalui program pembaruan yang ditawarkannya. Di zaman klasik Islam, madrasah telah mengawali kemajuan Islam dalam bidang kebudayaan dan peradaban yang hasilnya dinikmati masyarakat dunia. Pada zaman penjajahan Belanda dan Jepang, madrasah telah berjasa selain memberikan pencerahan dan penyadaran tentang pentingnya kemerdekaan hidup, juga telah memberikan pendidikan yang bermutu yang memungkinkan umat Islam Indonesia dapat ikut andil dalam memerdekakan Indonesia. Pada zaman orde baru, titik tekannya pada pembangunan ekonomi yang ditopang oleh stabilitas politik dan keamanan, madrasah telah berjasa melahirkan putra-putri terbaiknya yang selanjutnya dapat berkiprah dalam seluruh aspek kehidupan bangsa. Selanjutnya di era reformasi dan globalissi seperti saat ini, madrasah juga telah melakukan re-evaluasi dan reformasi terhadap visi, misi tujuan, kurikulum dan berbagai komponen pendidikannya yang disesuaikan dengan kebutuhan zaman. Dengan berbagai upaya ini, kini sudah banyak madrasah telah tampil sejajar bahkan lebih unggul dibandingkan pendidikan umum lainnya. 


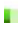

\section{VOLUME 14 NOMOR 1 TAHUN 2021}

P-ISSN : 1979-9357

E-ISSN : 2620-5858

Madrasah telah memberikan sumbangan yang signifikan dalam rangka mencerdaskan bangsa Indonesia pada umumnya dan dalam rangka membina manusia yang unggul seutuhnya, yakni intelektualitas, jasmani, rohani, akhlak moral, ketrampilan dan pengalaman. Para lulusan madrasah kini telah memainkan peranan penting dalam segala bidang kehidupan masyarakat, sehingga kini kepercayaan dan animo masyarakat untuk menyekolahkan putra-putrinya di madrasah semakin meningkat. Madrasah telah menjadi pilihan utama masyarakat.

\section{DAFTAR PUSTAKA}

Ahid, Nur. 2013. "Problem Pengelolaan Madrasah Aliyah Dan Solusinya." Islamica $4(2)$.

Ahmad, Zakaria. 1972. Sekitar Keradjaan Atjeh Dalam Tahun 1520-1675. Medan: Penerbit Monora.

Al-Abrasyi, Athiyah. 1993. Dasar-Dasar Pokok Pendidikan Islam. Jakarta: Bulan Bintang.

Anwar, Ali. 2010. Pembaharuan Pendidikan Di Pesantren Lirboyo Kediri. Jogyakarta: Pustaka Pelajar.

Asari, Hasan. 1994. Menyingkap Zaman Keemasan Islam. Bandung: Mizan.

Asrohah, Hanun. 1999. Sejarah Pendidikan Islam. ed. Jolanda van der Noll. Jakarta: Logos Wacana.

Azra, Azyumardi. 1999. Esai-Esai Intelektual Muslim Dan Pendidikan Islam. Jakarta: Logos.

- - 2017. Surau Pendidikan Islam Tradisional Dalam Transisi Dan Modernisasi. lst ed. Jakarta: Logos Wacana Ilmu.

Bullier, Richard W. 1972. The Patrician of Nisaphur: A Study in Medieval Islamic Social History. United States of America: Harvard University Press.

Daulay, Haidar Putra. 2004. Pendidikan Islam Dalam Sistem Pendidikan Nasional Indonesia. Jakarta: Kencana.

_- - 2007. Sejarah Pertumbuhan Dan Pembaharuan Pendidikan Islam Di Indonesia. lst ed. Jakarta: Putra Grafika.

Departemen Agama RI. 2001. Menelusuri Pertumbuhan Madrasah Di Indonesia. Jakarta: Direktorat Jenderal Kelembagaan Agama Islam.

Fatchurrochman, Nanang. 2012. Madrasah: Sekolah Islam Terpadu; Plus Dan Unggulan. Depok: Lendean Hati Pustaka.

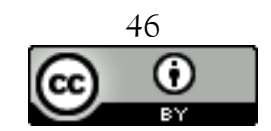

This work is licensed under a Creative Commons Attribution 4.0 International License 
VOLUME 14 NOMOR I TAHUN 2021

P-ISSN : 1979-9357

E-ISSN : $2620-5858$

Hasbullah. 1995. Sejarah Pendidikan Islam Di Indonesia: Lintasan Sejarah Pertumbuhan Dan Perkembangan. PT. Logos Wacana Ilmu.

Hasjmy. 1978. Iskandar Muda Meukuta Alam. Jakarta: Bulan Bintang.

Hurgronje, C. Snouck. 1996. ACEH Rakyat Dan Adat Istiadat. Jakarta: INIS.

Husein, Ibrahim. 1995. “Sejarah Singkat Pendidikan Di Aceh.” In Perkembangan

Pendidikan Di Daerah Istimewa Aceh, ed. Adnan Adullah H. Badruzzaman Ismail, H. Mahyuddin Hasyim. Banda Aceh: Majelis Pendidikan Daerah Provinsi NAD.

Ibrahim, Muslim. 1993. "Pengembaraan Kebudayaan Aceh Di Luar Tanah Ranahnya.” In Islam Dan Kebudayaan Indonesia: Dulu, Kini Dan Esok, Jakarta: Yayasan Festival Istiqlal.

Idris, Safwan. "Perkembangan Pendidikan Pesantren/Dayah (Antara Tradisi Dan Pembaharuan).” In Perkembangan Pendidikan Di Daerah Istimewa Aceh, , 50-71.

Ismail, Badruzzaman. 2002. Mesjid Dan Adat Meunasah Sebagai Sumber Energi Budaya Aceh. Banda Aceh: Majelis Pendidikan Daerah Provinsi NAD.

Kelly, A.V. 2004. The Curriculum Theory and Practice. London: Sage Publication.

Lombard, Denys. 2006. Kerajaan Aceh Zaman Sultan Iskandar Muda (1607-1636). Jakarta: Kepustakaan Populer Gramedia.

Makdisi, George. 1981. The Rise of Colleges, Institution of Learning in Islam and the West. Edinburgh: Edinburgh University Press.

Maksum. 1999. Madrasah;Sejarah Dan Perkembangannya. Jakarta: Logos Wacana Ilmu.

Mohammad Kasim. 2007. "Madrasah Di Indonesia: Pertumbuhan Dan Perkembangan.” TADRIS: Jurnal Pendidikan Islam 2(1).

Muhaimin. 2005. Pengembangan Kurikulum Pendidikan Agama Islam, Di Sekolah, Madrasah Dan Perguruan Tinggi. Jakarta: Rajawali Press.

Mukti, Abd. 2007. Konstruksi Pendidikan Islam (Belajar Dari Kejayaan Madrasah Nizamiyah Dinasti Saljuq. 1st ed. Bandung: Citapustaka Media.

Nakosteen, Mehdi. 1964. History of Islamic Origins of Western Education A.D. 800-1350, with an Introduction to Medieval Muslim Education. Colorado: University of Colorado Press, Boulder.

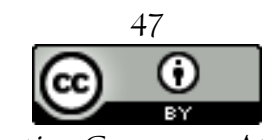


VOLUME 14 NOMOR I TAHUN 2021

P-ISSN : 1979-9357

E-ISSN : 2620-5858

Nata, Abuddin. 2001. Sejarah Pertumbuhan Dan Perkembangan Lembaga-Lembaga Pendidikan Islam Di Indonesia. Jakarta: Grasindo bekerja sama dengan IAIN Jakarta.

-_- 2010. Manajemen Pendidikan Islam: Mengatasi Kelemahan Pendidikan Islam Di Indonesia. ed. 4. Jakarta: Kencana.

Rahim, Husni. 2001. Arah Baru Pendidikan Islam Di Indonesia. Jakarta: PT. Logos Wacana Ilmu.

—__ 2004. “Anatomi Madrasah Di Indonesia.” Edukasi: Jurnal Penelitian Pendidikan Agama dan Keagamaan 2(2).

Rukiati, and Hikmawati. 2006. Sejarah Pendidikan Islam Di Nusantara. Bandung: Pustaka Setia.

Salaby, Ahmad. 1970. Sejarah Kebudayaan Islam. Jakarta: Jayamurni.

——_. 1973. Sejarah Pendidikan Islam. Jakarta: Bulan Bintang.

—_—. 1990. Al-Tarbiyyah Al-Islâmiyyah, Nuzhûmuhâ, Falsafatuhâ, Târîkhuhâ. Jakarta: Bulan Bintang.

Shaleh, Abdul Rachman. 2004. Madrasah Dan Pendidikan Anak Bangsa: Visi, Misi Dan Aksi. Jakarta: RajaGrafindo Persada.

Shaleh, Abdul Rahman. 2005. Pendidikan Agama Dan Pembangunan Watak Bangsa. Jakarta: RajaGrafindo Persada.

Stanton, Charles Michael. 1994. Pendidikan Tinggi Dalam Islam. Jakarta: Logos Publishing House.

Steenbrink, Karel. A. 1991. Pesantren Madrasah Sekolah. Jakarta: LP3ES.

Syafaat, Ibnu. 201l. “Madrasah Multikultural Dari Timur.” Hidayatullah.

Tibawi, A.L. 1979. Islamic Education; Its Tradition and Modernization into the Arab. London: Luzac and Company Ltd.

Tilaar, H.A.R. 2009. Kekuasaan Dan Pendidikan; Manajemen Pendidikan Nasional Dalam Pusaran Kekuasaan. Jakarta: Rineka Cipta.

Yunus, Mahmud. 1992. Sejarah Pendidikan Islam. Jakarta: Hidakarya, Agung.

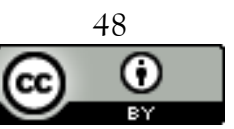




\section{AT-TAFRIR}

1

VOLUME 14 NOMOR I TAHUN 2021

P-ISSN : 1979-9357

E-ISSN : 2620-5858

Zulhandra. 2009. "Pola Dan Kebijakan Pendidikan Islam Pada Masa Awal Orde Lama (Orla).” In Sejarah Pendidikan Islam, ed. Samsul (ed.) Nizar. Jakarta: Kencana Prenada Group, 340-54. 